\title{
Seed Priming with Sulfhydral Thiourea Enhances the Performance of Camelina sativa L. under Heat Stress Conditions
}

\author{
Ejaz Ahmad Waraich ${ }^{1, *(1)}$, Muhammad Ahmad ${ }^{1}\left(\mathbb{D}\right.$, Walid Soufan ${ }^{2}(0)$, Muhammad Taimoor Manzoor ${ }^{1}$, \\ Zahoor Ahmad ${ }^{3}$, Muhammad Habib-Ur-Rahman ${ }^{4}{ }^{-}$and Ayman EL Sabagh ${ }^{5, *}$
}

check for

updates

Citation: Waraich, E.A.; Ahmad, M.; Soufan, W.; Manzoor, M.T.; Ahmad, Z.; Habib-Ur-Rahman, M.; Sabagh, A.E. Seed Priming with Sulfhydral Thiourea Enhances the Performance of Camelina sativa L. under Heat Stress Conditions. Agronomy 2021, 11, 1875. https: / / doi.org/10.3390/ agronomy11091875

Academic Editors: Channapatna S. Prakash, Ali Raza, Xiling Zou and Daojie Wang

Received: 15 August 2021

Accepted: 16 September 2021

Published: 17 September 2021

Publisher's Note: MDPI stays neutral with regard to jurisdictional claims in published maps and institutional affiliations.

Copyright: (c) 2021 by the authors. Licensee MDPI, Basel, Switzerland. This article is an open access article distributed under the terms and conditions of the Creative Commons Attribution (CC BY) license (https:/ / creativecommons.org/licenses/by/ $4.0 /)$.
1 Department of Agronomy, University of Agriculture Faisalabad, Faisalabad 38040, Pakistan; ahmadbajwa516@gmail.com (M.A.); taimoorpansota95@gmail.com (M.T.M.)

2 Plant Production Department, College of Food and Agriculture Sciences, King Saud University, P.O. Box 2460, Riyadh 11451, Saudi Arabia; wsoufan@ksu.edu.sa

3 Department of Botany, Bahawalpur Campus, University of Central Punjab, Bahawalpur 63100, Pakistan; zahoorahmadbwp@gmail.com

4 Institute of Crop Science and Resource Conservation (INRES), Crop Science, University of Bonn, 53115 Bonn, Germany; mhabibur@uni-bonn.de

5 Department of Agronomy, Faculty of Agriculture, Kafrelsheikh University, Kafrelsheikh 33516, Egypt

* Correspondence: uaf_ewarraich@yahoo.com (E.A.W.); ayman.elsabagh@agr.kfs.edu.eg (A.E.S.)

\begin{abstract}
Temperature is a key factor influencing plant growth and productivity; however, temperature fluctuations can cause detrimental effects on crop growth. This study aimed to assess the effect of seed priming on Camelina sativa L. under heat stress. Experimental treatments were comprised of; seed priming including, no-priming, hydropriming (distilled water priming), and osmopriming (thiourea applications at $500 \mathrm{ppm}$ ), heat stress (control $=20^{\circ} \mathrm{C}$ and heat stress $=32{ }^{\circ} \mathrm{C}$ ), and camelina varieties (7126 and 8046). Heat stress hammered crop growth as relative water content and photosynthetic rate were reduced by $35.9 \%$ and $49.05 \%$ in 7126 , respectively, and $25.6 \%$ and $41.2 \%$ in 8046 as compared with control-no thiourea applied. However, osmopriming with thiourea improved the root and shoot length, and biomass production compared to control-no application under heat stress, with more improvement in variety 8046 as compared with 7126 . Moreover, the maximum values of gas exchange and water relations were recorded at thiourea priming and no stress as compared with no-priming under heat stress that helped to improve seed yield by $12 \%$ in 7126 and 15\% in 8046, respectively. Among the varieties, camelina variety 8046 showed better performance than 7126 by producing higher seed yield especially when subjected to thiourea priming. In conclusion, thiourea seed priming helped the plants to mitigate the adverse effects of heat stress by upregulating plant physiological attributes that lead to maintain camelina seed yield.
\end{abstract}

Keywords: gas exchange; hydropriming; osmoprimimg; water relations; yield

\section{Introduction}

The world's population has been projected to cross 10 billion by 2050, which will significantly increase the demand for food supply [1], while climate change has already threatened food safety. Abiotic stresses have reduced the productivity of the staple crops, which has multiplied the existing challenge of food and nutritional security [2,3]. According to NASA [4,5], the first decade of the 21st century was the hottest in human history, which had huge impacts on agriculture productivity. Various climatic models predict that there will be a significant rise in the Earth's average annual temperature due to the increasing $\mathrm{CO}_{2}$ concentration [6] that will lead to a significant reduction in crop yield and reduced the farmer's income drastically [7]. Heat stress could impart numerous phenological, morphological, and physicochemical changes in crop plants. Considering all the climatic 
challenges, heat stress at seed formation had the primary role in affecting final yield and quality of oilseed crops.

In the wake of rising temperature, the emphasis should be on crop health [8] because crops require optimal temperature for proper development, and camelina is no exception. The effects of high temperature may hamper the performance of the photosynthetic apparatus that could lead to reduce carbon assimilation to reduce crop growth. Chemical signaling mechanisms in the thylakoids and carbon metabolism are more prone to heat stress damages [9], as high-temperature damages photosystem II that affects the electron transport chain and glycolate pathway due to the overproduction of reactive oxygen species (ROS; such as hydrogen peroxide, $\mathrm{H}_{2} \mathrm{O}_{2}$ ) [10]. High temperature severely influences the mineral and water transport system of plant tissues, which results in mineral deficiency and decreased turgidity [11,12]. Crop yield may decrease up to $10-15 \%$ due to each degree $\left({ }^{\circ} \mathrm{C}\right)$ rise in temperature above the optimum [13]. Plants have developed several mechanisms to reduce ROS levels in plant cells [14] by activating enzymatic and non-enzymatic scavenging systems [15]. Heat stress at any crop stage can cause substantial yield losses in Brassica crops [16]. Camelina has shown a substantial reduction in photosynthetic efficiency and crop yield when grown under high-temperature stress [17]. Ahmad et al. [16] have reported a reduction in the performance of camelina under heat-stressed conditions due to the impairment of plant physiological attributes. Temperature above $32{ }^{\circ} \mathrm{C}$ is critical at the reproductive growth stage and tends to decreased crop yield by the pod abortion, decreasing the number of seeds per plant, and seed weight [17]. Innovative and sustainable methods need to be introduced to improve the performance of crops under heat stress. Recently, thiourea (TU) emerged as one of the effective approaches to enhance high-temperature stress tolerance in plants by regulating metabolic balance, plant growth, and development [18].

Seed priming is a controlled hydration technique that accelerates the key metabolites for osmotic up-regulation [19]. Priming is one of the most feasible and economic technologies enabling the efficient uptake of nutrients, boosting water use efficiency, breaking seed dormancy, promoting early maturity, and improving crop physiology that ensures successful crop production $[20,21]$. It has been reported that osmopriming enhanced the antioxidant defense system under stressful conditions [22] to improve the defense system against heat stress. In addition, TU modulates the activity of numerous biological compounds such as plant growth regulators, polyamines, enzymes, mineral nutrients, and produces many derivatives, which have the potential to mitigate heat stress damages [23]. It has a major role in the production of proteins, vitamins, enzymes, and chlorophyll in plant cells and tissues from vegetative growth to maturity [24]. Interaction of TU-containing compounds with various biological compounds produces specific derivatives essential for enhancing thermo-tolerance by modulating the ROS scavenging system [25]. The applications of TU may upregulate enzymatic activities in different plant parts that help to remove the ROS, by activating the ascorbate-glutathione cycle to alleviate heat stress $[26,27]$. Nonetheless, optimal quantity is vital for TU-induced increase in antioxidant activities that contributed to reverse the high temperature stress [28,29]. The heat stress-induced damages can be ameliorated by the pre-sowing seed treatments with different chemical agents, which may be useful for the generation of heat-stress tolerance in plants.

Camelina [Camelina sativa L. Crantz] is an emerging oilseed crop with unique characteristics in relation to its high adaptability against abiotic stresses [30]. Its oil constitutes a vital product for the bio-based industries, as its distinctive composition permits multiple applications [31]. It is a rediscovered oil crop that belongs to the family Brassicaceae, having a seed oil content of $26-43 \%[32,33]$ with high percentage of unsaturated fatty acids. The seeds of camelina are unique compared to other members of Brassicaceae due to their high amount of polyunsaturated fatty acids and low level of erucic acid. Regular ingestion of camelina oil reduces the level of cholesterol in blood and the presence of tocopherols prevents the oil from rancidity [34]. According to Zubr [35], Camelina can be adapted to various environmental conditions including limited water conditions, high and low tem- 
peratures, etc. Camelina is popularly known as false flax, which is typically a cool-season crop with a temperature that seldomly exceeds $30^{\circ} \mathrm{C}$ [36]; however, it can be grown in the winter and spring seasons [37].

However, the role of TU has been documented under abiotic stress tolerance, while the role of TU to alleviate heat stress damages in camelina needs further investigation. The study was hypothesized that TU priming regulates the heat stress tolerance in camelina. The objective of the study was to evaluate the impact of seed priming techniques on growth and yield parameters on physiological basis in camelina under heat stress conditions.

\section{Materials and Methods}

\subsection{Crop Husbandry}

The pot experiment was laid out under completely randomized design (CRD) with factorial arrangements and three replications. Camelina seeds (10 seeds) were sown in plastic pots $(36 / 24 \mathrm{~cm})$ containing $5 \mathrm{~kg}$ of sand, while each pot was considered as a biological replicate. Camelina seeds were obtained from the Stress Physiology Laboratory, Department of Agronomy, University of Agriculture, Faisalabad. Sand was sieved to opt-out all the contaminants, and then field capacity was calculated through proper procedure. The experiment was comprised of three factors: (a) seed priming; $\mathrm{TU}_{0}=$ control-no priming, $\mathrm{TU}_{1}=$ hydropriming (water priming), and $\mathrm{TU}_{2}=$ osmopriming ( $\mathrm{TU}$ primming at $500 \mathrm{ppm}$ ), (b) heat stress; control $-20 / 18^{\circ} \mathrm{C}$ day /night and heat stress- $32 / 22{ }^{\circ} \mathrm{C}$ day and night at 65 days after sowing (DAS), and (c) camelina varieties (7126 and 8046). The screening experiment was done at stress physiology laboratory, which led us to select the one resistant (8046) and one susceptible (7126) variety for this study. The Hoagland solution $\left(\mathrm{NH}_{4} \mathrm{H}_{2} \mathrm{PO}_{4} 1 \mathrm{mM} ; \mathrm{Ca}\left(\mathrm{NO}_{3}\right)_{2} \cdot 4 \mathrm{H}_{2} \mathrm{O} 4 \mathrm{mM} ; \mathrm{KNO}_{3} 6 \mathrm{mM} ; \mathrm{MnCl}_{2} \cdot 4 \mathrm{H}_{2} \mathrm{O} 9.1 \mu \mathrm{M} ; \mathrm{H}_{3} \mathrm{BO}_{3}\right.$ $46.2 \mu \mathrm{M} ; \mathrm{CuSO}_{4} \cdot 5 \mathrm{H}_{2} \mathrm{O} 0.3 \mu \mathrm{M} ; \mathrm{ZnSO}_{4} \cdot 7 \mathrm{H}_{2} \mathrm{O} 0.8 \mu \mathrm{M} ; \mathrm{MgSO}_{4} \cdot 7 \mathrm{H}_{2} \mathrm{O} 2 \mathrm{mM} ; \mathrm{Fe}-\mathrm{Na}_{2}$-EDTA $0.1 \mathrm{mM}$.) was applied for the nutritional requirements of camelina. The application of Hoagland solution was done at the time of sowing and topped up after every fortnight.

Seeds of both varieties were separately soaked for the hydro-priming and osmopriming (TU solution) for $6 \mathrm{~h}$. For hydro-priming, seeds were soaked in the distilled water for $6 \mathrm{~h}$ while TU (500 ppm) solution was used for the osmopriming, and continuous aeration was provided by using an aquarium pump to avoid anxious conditions. The experiment was comprised of 36 pots and grouped into two sets containing 18 pots in each, which were grown under the same conditions until heat stress was applied on one set. Stress was induced just before the onset of the flowering stage by increasing the temperature of the growth room from $20^{\circ} \mathrm{C}$ (control) to $32{ }^{\circ} \mathrm{C}$ (heat stress). The experiment was performed in a growth room having a mechanized unit of cooling, heating, light $(\sim 12,000$ lux), and humidifier/dehumidifier adjustment systems. Relative humidity $(70 \%)$ was maintained in the growth rooms and water was provided regularly for achieving the field capacity to prevent drought stress. Then, the temperature was gradually increased by $2{ }^{\circ} \mathrm{C}$ each day to avoid any heat shock to seedlings till it reached $32 / 22{ }^{\circ} \mathrm{C}$ day/night. The stress lasts for 10 days as it reached to maximum temperature and came back with the same way. Gas exchange attributes were measured at 76 DAS after imposition of stress, while growth parameters were measured at $80 \mathrm{DAS}$, while seed yield and related parameters were measured at 108 DAS.

\subsection{Growth Parameters}

For the measurement of growth parameters, two uniform plants were randomly selected from each biological replicate. Plant height and root length was measured using a meter rod from the surface of the soil to the tip of the plant. Pots were filled with water to gently uproot the randomly selected plants and averaged. The length of five roots was taken by using a meter rod from the uprooted plants and averaged. These samples were cleaned and washed with distilled water, and root and shoot were separated by a pair of scissors. After cleaning, the fresh weight of root and shoot was taken by using a digital balance (Uni Block AUX220, Shimadzu Corporation, Kyoto, Japan). These samples were 
oven-dried (Memmert-110, Schawabach, Germany) at $70{ }^{\circ} \mathrm{C}$ for $72 \mathrm{~h}$ to take dry weight by using a digital balance.

\subsection{Gas Exchange Parameters}

Different physiological traits including photosynthetic rate $(A)$, transpiration rate $(E)$, stomatal conductance $(g s)$, and internal $\mathrm{CO}_{2}$ concentration $(C i)$ were measured by using an open system, portable infrared gas analyzer (IRGA) (LCA-4 ADC (USA)). The fully expanded young leaves of three plants selected randomly from each pot were used to measure these attributes. Measurements were made between 9:00 a.m. and 10:00 a.m. to opt-out of the effect of high temperature. The following adjustments were made for these measurements; leaf surface area $6.25 \mathrm{~cm}^{2}$, ambient $\mathrm{CO}_{2}$ concentration $\left(326 \mu \mathrm{molmol}^{-1}\right)$, the temperature of the leaf chamber ranged from 31.5 to $37.8^{\circ} \mathrm{C}$, ambient pressure $(\mathrm{P})$ $98.2 \mathrm{k} \mathrm{Pa}$, chamber gas flow rate (V) $408 \mathrm{~mL} \mathrm{~min}^{-1}$, the molar flow of air per unit leaf area (Us) 409.5 molm $^{-2} \mathrm{~s}^{-1}$, the water vapor pressure in the chamber (ref.) ranged 21.2-24 mbar, and PAR at leaf surface was maximum up to $1181 \mu \mathrm{mol} \mathrm{m}^{-2} \mathrm{~s}^{-1}$.

\subsection{Water Relations}

To observe leaf water potential, the top third youngest and fully expanded leaf of camelina plants was harvested from each treatment. Scholander-type pressure chamber (ARIMAD-2, ELE-International, Tokyo, Japan) according to the method defined by Ahmad et al. [17].

\subsection{Yield and Related Attributes}

Yield component, i.e., a number of silique per plant and number of seed per silique were measured from two tagged plants per pot and averaged. A 1000 seed weight was taken from two representative plants from each biological replicate and seeds were taken to measure 1000 seed weight by using a digital balance (Uni Block AUX220, Shimadzu Corporation, Kyoto, Japan). Each pot was manually harvested, seeds were separated, and the seed yield per pot was obtained using a digital balance.

\subsection{Statistical Analysis}

Data collected were statistically analyzed through analysis of variance technique using Statistix 10.1 (Analytical Software, Statistix, Tallahassee, FL, USA). Fisher's analysis of variance was used to compare the treatment means at a 5\% probability level [38]. Graphical representation was done by using SigmaPlot 10.0.

\section{Results}

\subsection{Growth Parameters}

Analysis of variance showed that TU supplementation significantly affected the growth parameters in camelina varieties under different environments compared to controlno TU (Table 1). Heat stress reduced the growth attributes in camelina varieties, while more reduction was noted in camelina with no TU supplementation under heat stress. Plant height was reduced by $23.7 \%$ and $30.5 \%$ in 8046 and 7126 , respectively, under heat stress as compared to control-no stress. Different growth parameters such as plant height, root length, root-shoot length, and their fresh and dry weight were significantly improved with TU priming under normal as well as heat stress conditions (Table 1). Nevertheless, plant height was improved by $27.5 \%$ in 8046 and 19.4\% in 7126, respectively, which showed higher improvement in variety 8046 compared with 7126 with TU priming compared to control-no TU. Results showed that seed priming with TU performed better in all the mentioned characters and improved these growth characters under normal temperature (control) as well as under high-temperature stress conditions. In addition, camelina variety 8046 performed better for all growth parameters with osmopriming under normal and heat stress conditions compared to 7126 (Table 1). Maximum values of growth attributes including plant height $(64.5 \mathrm{~cm})$ and root length $(17.2 \mathrm{~cm})$ were observed at $\mathrm{TU}_{2}(\mathrm{TU}$ 
priming), $\mathrm{T}_{1}\left(2{ }^{\circ} \mathrm{C}\right)$, and $\mathrm{V}_{2}$ (8046), while minimum values of growth attributes including plant height $(33.6 \mathrm{~cm})$ and root length $(7.38 \mathrm{~cm})$ were observed at $\mathrm{TU}_{0}$ (control-no priming), $\mathrm{T}_{2}\left(32{ }^{\circ} \mathrm{C}\right)$, and $\mathrm{V}_{1}(7126)$. Among the seed priming, hydro-priming showed an increase of $8.99 \%$ in plant height and TU-seed priming showed an increase of $23.6 \%$ in plant height as compared to control-no priming.

Table 1. Impact of thiourea priming and heat stress on growth parameters of two camelina varieties.

\begin{tabular}{|c|c|c|c|c|c|c|c|c|}
\hline Varieties (V) & $\begin{array}{l}\text { Heat Stress } \\
\text { (T) }\end{array}$ & $\begin{array}{l}\text { Thiourea (TU) } \\
\text { Applications }\end{array}$ & $\begin{array}{l}\text { Plant Height } \\
\text { (cm) }\end{array}$ & $\begin{array}{l}\text { Root Length } \\
\text { (cm) }\end{array}$ & $\begin{array}{l}\text { Shoot Fresh } \\
\text { Weight (g) }\end{array}$ & $\begin{array}{l}\text { Root Fresh } \\
\text { Weight (g) }\end{array}$ & $\begin{array}{l}\text { Shoot Dry } \\
\text { Weight (g) }\end{array}$ & $\begin{array}{c}\text { Root Dry } \\
\text { Weight (g) }\end{array}$ \\
\hline \multirow{6}{*}{7126} & \multirow{3}{*}{ Control } & $\mathrm{TU}_{0}$ & $52.7 \pm 1.25^{\mathrm{d}}$ & $9.19 \pm 0.15^{\mathrm{f}}$ & $4.04 \pm 0.06^{\mathrm{d}}$ & $1.41 \pm 0.004^{\mathrm{e}}$ & $0.56 \pm 0.02^{\mathrm{d}}$ & $0.08 \pm 0.003^{f}$ \\
\hline & & $\mathrm{TU}_{1}$ & $55.5 \pm 0.56^{c}$ & $10.3 \pm 0.51^{\mathrm{e}}$ & $4.61 \pm 0.21^{\mathrm{c}}$ & $1.47 \pm 0.02^{\mathrm{c}, \mathrm{d}}$ & $0.60 \pm 0.01^{c}$ & $0.09 \pm 0.002^{\mathrm{d}, \mathrm{e}}$ \\
\hline & & $\mathrm{TU}_{2}$ & $58.5 \pm 2.17^{b}$ & $11.9 \pm 0.61^{c}$ & $5.35 \pm 0.20^{b}$ & $1.50 \pm 0.005^{c}$ & $0.72 \pm 0.01^{\mathrm{b}}$ & $0.10 \pm 0.002^{b}$ \\
\hline & \multirow{3}{*}{ Heat stress } & $\mathrm{TU}_{0}$ & $33.6 \pm 1.00 \mathrm{~g}$ & $7.37 \pm 0.17^{g}$ & $2.13 \pm 0.10^{\mathrm{h}}$ & $1.11 \pm 0.01^{\mathrm{i}}$ & $0.21 \pm 0.002^{g}$ & $0.04 \pm 0.001^{\mathrm{i}}$ \\
\hline & & $\mathrm{TU}_{1}$ & $37.6 \pm 1.21^{\mathrm{f}}$ & $8.91 \pm 1.12^{\mathrm{f}}$ & $2.47 \pm 0.05 \mathrm{~g}$ & $1.15 \pm 0.01^{\mathrm{h}}$ & $0.22 \pm 0.01 \mathrm{~g}$ & $0.05 \pm 0.001^{h}$ \\
\hline & & $\mathrm{TU}_{2}$ & $45.2 \pm 1.42^{\mathrm{e}}$ & $11.6 \pm 0.22^{\mathrm{c}, \mathrm{d}}$ & $2.92 \pm 0.40^{\mathrm{f}}$ & $1.21 \pm 0.01^{\mathrm{g}}$ & $0.29 \pm 0.01^{\mathrm{f}}$ & $0.09 \pm 0.00^{\mathrm{f}}$ \\
\hline \multirow{6}{*}{8046} & \multirow{3}{*}{ Control } & $\mathrm{TU}_{0}$ & $54.5 \pm 0.15^{\mathrm{c}, \mathrm{d}}$ & $12.09 \pm 1.17^{c}$ & $4.27 \pm 0.02^{\mathrm{d}}$ & $1.45 \pm 0.002^{\mathrm{d}, \mathrm{e}}$ & $0.63 \pm 0.01^{c}$ & $0.09 \pm 0.002^{\mathrm{e}}$ \\
\hline & & $\mathrm{TU}_{1}$ & $60.6 \pm 0.62$ & $13.2 \pm 1.57^{\mathrm{b}}$ & $5.13 \pm 0.14^{b}$ & $1.55 \pm 0.02^{\mathrm{b}}$ & $0.72 \pm 0.02^{b}$ & $0.10 \pm 0.002^{c}$ \\
\hline & & $\mathrm{TU}_{2}$ & $64.5 \pm 0.86^{\mathrm{a}}$ & $17.2 \pm 0.50^{\mathrm{a}}$ & $6.01 \pm 0.17^{\mathrm{a}}$ & $1.60 \pm 0.04^{\mathrm{a}}$ & $0.82 \pm 0.004^{a}$ & $0.13 \pm 0.005^{a}$ \\
\hline & \multirow{3}{*}{ Heat stress } & $\mathrm{TU}_{0}$ & $39.2 \pm 0.66^{f}$ & $10.7 \pm 0.05^{\mathrm{d}, \mathrm{e}}$ & $2.74 \pm 0.03^{f, g}$ & $1.15 \pm 0.01^{\mathrm{h}}$ & $0.29 \pm 0.01^{f}$ & $0.06 \pm 0.00^{\mathrm{h}}$ \\
\hline & & $\mathrm{TU}_{1}$ & $46.6 \pm 1.69^{\mathrm{e}}$ & $13.1 \pm 0.53^{b}$ & $2.96 \pm 0.04^{\mathrm{f}}$ & $1.22 \pm 0.01 \mathrm{~g}$ & $0.32 \pm 0.01^{\mathrm{f}}$ & $0.07 \pm 0.00 \mathrm{~g}$ \\
\hline & & $\mathrm{TU}_{2}$ & $55.0 \pm 2.00^{c}$ & $16.3 \pm 0.74^{\mathrm{a}}$ & $3.56 \pm 0.03^{\mathrm{e}}$ & $1.29 \pm 0.02^{f}$ & $0.47 \pm 0.03^{\mathrm{e}}$ & $0.09 \pm 0.00^{\mathrm{d}}$ \\
\hline
\end{tabular}

Values (mean \pm standard deviation, $n=3$ ), $\mathrm{TU}_{0}=$ No thiourea priming, $\mathrm{TU}_{1}=$ Water priming, $\mathrm{TU}_{2}=$ Thiourea priming; $\mathrm{LSD}=$ least significant difference; values sharing same case letter or without lettering for a parameter do not differ significantly $(p \leq 0.05)$ by the LSD test.

Among the interactions, $\mathrm{TU} \times \mathrm{T}$ was significant for plant height, root and shoot fresh weight, and shoot dry weight. The interaction, $\mathrm{TU} \times \mathrm{V}$ was significant for plant height, root length, root fresh weight, and shoot dry weight in camelina. The interaction, $\mathrm{V} \times \mathrm{T}$ was significant for plant height, shoot fresh and dry weight.

\subsection{Physiological Parameters}

\subsubsection{Gas Exchange Attributes}

Analysis of variance showed that TU priming significantly influenced the physiological parameters under different environmental conditions (Table 2). Among the gas exchange attributes, photosynthetic rate and stomatal conductance were decreased, while transpiration and intercellular $\mathrm{CO}_{2}$ rates were increased under heat stress conditions as compared to control-no stress. The photosynthetic rate was decreased by $41.2 \%$ in 8046 and $49.2 \%$ in 7126 , respectively, while stomatal conductance was decreased by $19.4 \%$ in 8046 and $34.6 \%$ in camelina under heat stress over control-no stress. Maximum photosynthetic rate $\left(6.94 \mu \mathrm{mol} \mathrm{CO} \mathrm{m}^{-2} \mathrm{~s}^{-1}\right)$ and stomatal conductance $\left(0.079 \mathrm{~mol} \mathrm{H}_{2} \mathrm{O} \mathrm{m}^{-2} \mathrm{~s}^{-1}\right)$ were noted with osmopriming, while a lower value of these attributes $\left(2.04 \mu \mathrm{mol} \mathrm{CO} \mathrm{Cm}^{-2} \mathrm{~s}^{-1}\right.$, and $0.04 \mathrm{~mol} \mathrm{H}_{2} \mathrm{O} \mathrm{m}^{-2} \mathrm{~s}^{-1}$, respectively) was noted with control-no priming. Nevertheless, photosynthetic rate was improved by $44.3 \%$ in 8046 and $42 \%$ in 7126 with TU priming compared to control-no TU. Transpiration rate $\left(0.68 \mathrm{~mol} \mathrm{H}_{2} \mathrm{O} \mathrm{m}^{-2} \mathrm{~s}^{-1}\right)$ was increased, and internal $\mathrm{CO}_{2}$ rate $\left(344.4 \mu \mathrm{mol} \mathrm{CO} \mathrm{Col}^{-1}\right)$ was decreased with TU seed priming compared to control-no TU. In relation to camelina varieties, the 8046 variety was more tolerant to heat stress conditions compared to 7126 variety (Table 2). Among the varieties, higher values of photosynthetic rate $\left(5.11 \mu \mathrm{mol} \mathrm{CO} \mathrm{C}^{-2} \mathrm{~s}^{-1}\right)$ were noted in 8046 , while lower values $\left(3.67 \mu \mathrm{mol} \mathrm{CO} \mathrm{m}^{-2} \mathrm{~s}^{-1}\right)$ were noted in 7126 . Maximum values of gas exchange attributes including photosynthetic rate $\left(7.45 \mu \mathrm{mol} \mathrm{CO} \mathrm{CO}^{-2} \mathrm{~s}^{-1}\right)$ were observed at $\mathrm{TU}_{2}$ (TU priming), $\mathrm{T}_{1}\left(22^{\circ} \mathrm{C}\right)$, and $\mathrm{V}_{2}$, while minimum values of gas exchange attributes including photosynthetic rate $\left(2.05 \mu \mathrm{mol} \mathrm{CO} \mathrm{C}^{-2} \mathrm{~s}^{-1}\right)$ were observed at $\mathrm{TU}_{0}$ (control-no priming), $\mathrm{T}_{2}\left(32{ }^{\circ} \mathrm{C}\right)$, and $\mathrm{V}_{1}(7126)$. Among the seed priming, hydro-priming showed an increase of $18.07 \%$ in photosynthetic rate and TU-seed priming showed an increase of $43.3 \%$ in photosynthetic rate as compared to control-no priming 
Table 2. Impact of thiourea priming and heat stress on gas exchange attributes of two camelina varieties.

\begin{tabular}{|c|c|c|c|c|c|c|}
\hline Varieties (V) & Heat Stress $(\mathrm{T})$ & $\begin{array}{l}\text { Thiourea (TU) } \\
\text { Applications }\end{array}$ & $\begin{array}{l}\text { Photosynthetic Rate } \\
\left(\mu \mathrm{mol} \mathrm{H}_{2} \mathrm{O} \mathrm{m}^{-2} \mathrm{~s}^{-1}\right)\end{array}$ & $\begin{array}{l}\text { Transpiration Rate } \\
\left(\mathrm{mmol} \mathrm{m}^{-2} \mathrm{~s}^{-1}\right)\end{array}$ & $\begin{array}{c}\text { Stomatal } \\
\text { Conductance } \\
\left(\mathrm{mmol} \mathrm{m}^{-2} \mathrm{~s}^{-1}\right)\end{array}$ & $\begin{array}{c}\text { Intercellular } \mathrm{CO}_{2} \\
\text { Concentration } \\
\left(\mu \mathrm{mol} \mathrm{m}{ }^{-2} \mathrm{~s}^{-1}\right)\end{array}$ \\
\hline \multirow{6}{*}{7126} & \multirow{3}{*}{ Control } & $\mathrm{TU}_{0}$ & $4.05 \pm 0.02^{f}$ & $0.41 \pm 0.00^{h}$ & $0.05 \pm 0.00^{\mathrm{e}}$ & $278.1 \pm 1.43^{\mathrm{e}}$ \\
\hline & & $\mathrm{TU}_{1}$ & $4.75 \pm 0.06^{\mathrm{e}}$ & $0.47 \pm 0.00 \mathrm{~g}$ & $0.05 \pm 0.00^{\mathrm{d}}$ & $267.8 \pm 1.72^{f}$ \\
\hline & & $\mathrm{TU}_{2}$ & $5.78 \pm 0.06^{c}$ & $0.50 \pm 0.02^{\mathrm{f}}$ & $0.06 \pm 0.00^{c}$ & $254.3 \pm 2.15^{g}$ \\
\hline & \multirow{3}{*}{ Heat stress } & $\mathrm{TU}_{0}$ & $2.05 \pm 0.03^{j}$ & $0.43 \pm 0.00^{h}$ & $0.04 \pm 0.00^{h}$ & $344.3 \pm 3.72^{a}$ \\
\hline & & $\mathrm{TU}_{1}$ & $2.51 \pm 0.02^{j}$ & $0.48 \pm 0.01^{g}$ & $0.04 \pm 0.00^{g}$ & $331.0 \pm 2.75^{b}$ \\
\hline & & $\mathrm{TU}_{2}$ & $2.87 \pm 0.00^{h}$ & $0.49 \pm 0.00^{\mathrm{e}}$ & $0.04 \pm 0.00^{\mathrm{f}}$ & $311.0 \pm 2.75^{c}$ \\
\hline \multirow{6}{*}{8046} & \multirow{3}{*}{ Control } & $\mathrm{TU}_{0}$ & $5.42 \pm 0.37^{\mathrm{d}}$ & $0.56 \pm 0.00^{\mathrm{e}}$ & $0.06 \pm 0.00^{c}$ & $248.4 \pm 5.37^{g}$ \\
\hline & & $\mathrm{TU}_{1}$ & $6.42 \pm 0.37^{b}$ & $0.63 \pm 0.01^{c}$ & $0.07 \pm 0.00^{b}$ & $237.1 \pm 3.19^{h}$ \\
\hline & & $\mathrm{TU}_{2}$ & $7.45 \pm 0.01^{\mathrm{a}}$ & $0.67 \pm 0.01^{\mathrm{a}, \mathrm{b}}$ & $0.07 \pm 0.00^{\mathrm{a}}$ & $224.2 \pm 6.10^{i}$ \\
\hline & \multirow{3}{*}{ Heat stress } & $\mathrm{TU}_{0}$ & $3.07 \pm 0.06^{\mathrm{h}}$ & $0.60 \pm 0.00^{\mathrm{d}}$ & $0.04 \pm 0.00 \mathrm{~g}$ & $329.2 \pm 3.51^{b}$ \\
\hline & & $\mathrm{TU}_{1}$ & $3.53 \pm 0.11^{g}$ & $0.64 \pm 0.03^{b, c}$ & $0.04 \pm 0.00^{f}$ & $311.4 \pm 2.76^{c}$ \\
\hline & & $\mathrm{TU}_{2}$ & $4.76 \pm 0.08^{\mathrm{e}}$ & $0.68 \pm 0.00^{a}$ & $0.05 \pm 0.00^{\mathrm{d}}$ & $296.4 \pm 7.28^{d}$ \\
\hline
\end{tabular}

Values (mean \pm standard error, $n=3$ ), $\mathrm{TU}_{0}=$ No thiourea priming, $\mathrm{TU}_{1}=$ Water priming, $\mathrm{TU}_{2}=\mathrm{Thiourea}$ priming; $\mathrm{LSD}=$ least significant difference; values sharing same case letter or without lettering for a parameter do not differ significantly $(p \leq 0.05)$ by the LSD test.

Among the interactions, all interactions were significant for the photosynthetic rate. $\mathrm{TU} \times \mathrm{T}$ was significant for photosynthetic rate and intercellular $\mathrm{CO}_{2}$ rates. The $\mathrm{T} \times \mathrm{V}$ interaction remained significant for intercellular $\mathrm{CO}_{2}$ rates. The higher-order interaction $\mathrm{TU} \times \mathrm{T} \times \mathrm{V}$ was significant for stomatal conductance.

\subsubsection{Water Relations}

Seed priming significantly affected the plant water relations under heat stress (Figures 1 and 2). Heat stress reduced the plant water relations including water potential, osmotic potential, pressure potential, and relative water content as compared to control-no stress. Water potential decreased by $30 \%$ in 8046 and $33.7 \%$ in 7126 , respectively, and leaf relative water content was decreased by $25.6 \%$ in 8046 and $35.9 \%$ in 7126 , respectively, under heat stress over control-no stress. High values of water potential $(-0.80 \mathrm{MPa})$, osmotic potential, $(-1.33 \mathrm{MPa})$, pressure potential $(0.48 \mathrm{MPa})$, and relative water content (86.5\%), respectively, were noted with osmo-priming (TU priming) compared to control-no TU applied (Figures 1 and 2). Nevertheless, the relative water content was improved by $13.6 \%$ and pressure potential was increased by $29.5 \%$ with $\mathrm{TU}$ priming compared to control-no TU. In relation to camelina varieties, the 8046 variety was more tolerant to heat stress conditions compared to 7126 variety (Figures 1 and 2). In addition, higher values of water potential $(-1.00 \mathrm{MPa})$ were noted in 8046 , while lower values $(-1.09 \mathrm{MPa})$ were noted in 7126 . Maximum values of gas exchange attributes including water potential $(-0.79 \mathrm{MPa})$ were observed at $\mathrm{TU}_{2}$ ( $\mathrm{TU}$ priming), $\mathrm{T}_{1}\left(22^{\circ} \mathrm{C}\right)$ and $\mathrm{V}_{2}$, while minimum values of water relations including water potential $\left(-1.32 \mathrm{MPa}\right.$ ) were observed at $\mathrm{TU}_{0}$ (control-no priming), $\mathrm{T}_{2}\left(32^{\circ} \mathrm{C}\right)$, and $\mathrm{V}_{1}(7126)$. Among the seed priming, hydro-priming showed an increase of $15.05 \%$ in relative water content and TU-seed priming showed an increase of $60.9 \%$ in relative water content as compared to control-no priming.

Among the interactions, $\mathrm{TU} \times \mathrm{T}$ was significant for osmotic potential. The $\mathrm{T} \times \mathrm{V}$ was significant for water potential and relative water content. The higher-order interaction $\mathrm{TU} \times \mathrm{T} \times \mathrm{V}$ was significant for water potential.

\subsection{Yield and Related Attributes}

Analysis of variance showed that TU seed priming significantly affected the yield attributes in camelina varieties under high temperature stress (Table 1). Heat stress decreased the growth attributes in camelina varieties, while more reduction was noted with no-TU applications (Table 3). 

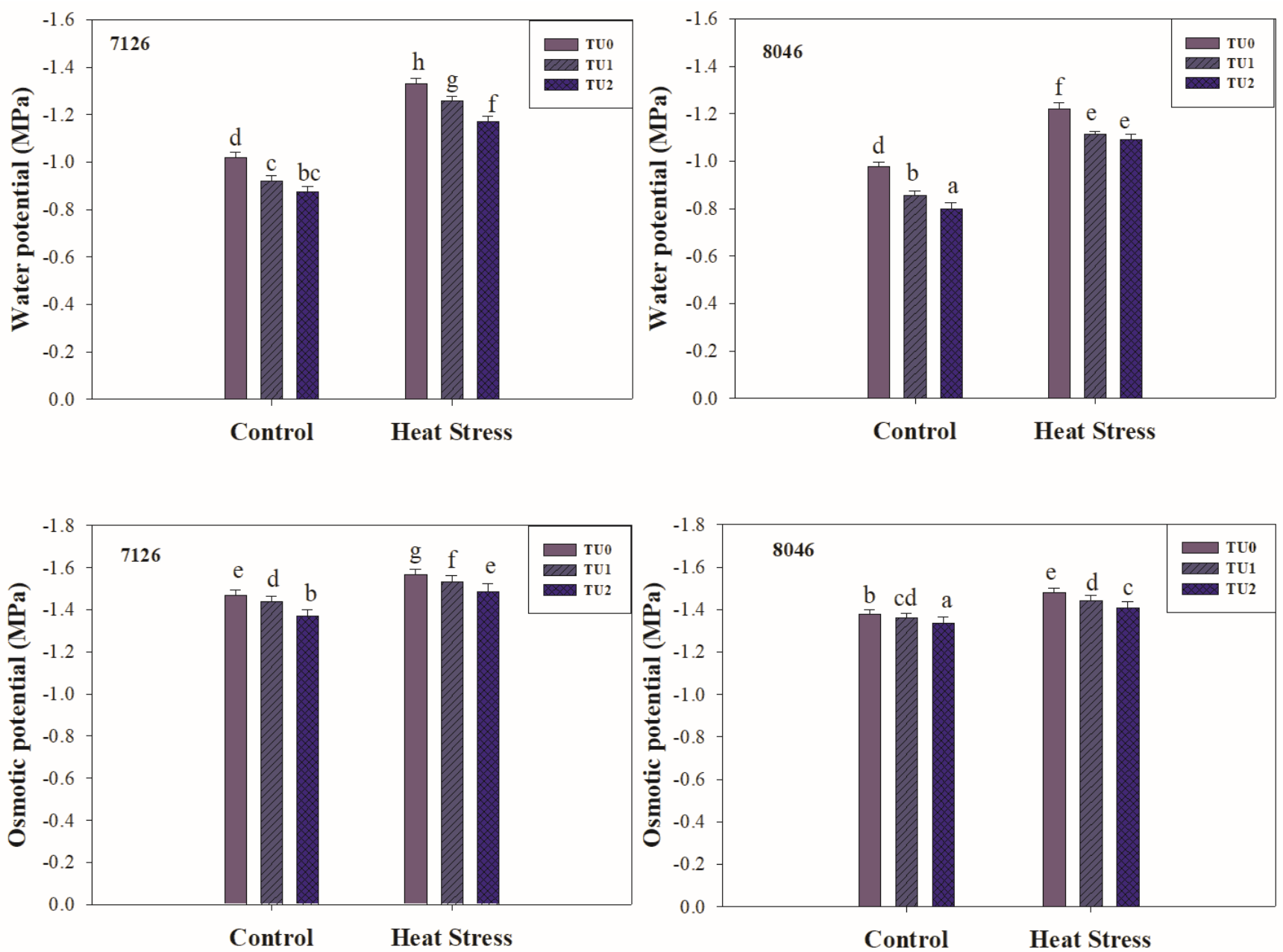

Figure 1. Impact of thiourea priming $\left(\mathrm{TU}_{0}=\right.$ control-no application, $\mathrm{TU}_{1}=$ Water priming, $\mathrm{TU}_{2}=\mathrm{Thiourea}$ priming $(500 \mathrm{ppm})$ and heat stress $\left(32^{\circ} \mathrm{C}\right)$ on water potential $(-\mathrm{MPa})$ and osmotic potential (-MPa) on camelina genotypes 7126 and 8046 . Error bars above means indicate the \pm S.E. Means sharing the same letter in both varieties do not differ significantly at $p \leq 0.05$.

Thousand seed weight was reduced by $28 \%$ in 8046 and $33.5 \%$ in 7126 , respectively, under heat stress conditions as compared to control-no stress. Yield traits such as the number of silicle per plant, number of seeds per silicle, thousand seed weight, and yield per pot were significantly higher under TU treatment as compared to control-no TU under heat stress conditions (Table 3). However, seed weight was improved by $41.2 \%$, and seed yield was improved by $65.6 \%$ with TU priming compared to control-no TU. Among the varieties, seed yield was improved by $63 \%$ in 8046 and $58.7 \%$ in 7126 which showed that seed yield was improved $11.7 \%$ more in 8046 as compared 7126 (Table 3). Maximum values of yield attributes including seed yield per pot $(3.91 \mathrm{~g})$ was observed at $\mathrm{TU}_{2}$ (TU priming), $\mathrm{T}_{1}\left(22{ }^{\circ} \mathrm{C}\right)$, and $\mathrm{V}_{2}$, while minimum values of yield attributes including photosynthetic rate $(0.59 \mathrm{~g})$ was observed at $\mathrm{TU}_{0}$ (control-no priming), $\mathrm{T}_{2}\left(32^{\circ} \mathrm{C}\right)$, and $\mathrm{V}_{1}(7126)$. Among the seed priming, hydro-priming showed an increase of $15.05 \%$ in seed yield and TU-seed priming showed an increase of $60.9 \%$ in seed yield as compared to control-no priming.

Among the interactions, $\mathrm{TU} \times \mathrm{T}$ was significant for the number of silicle/plant, number of seeds/silicle, and seed yield. The interaction, $\mathrm{TU} \times \mathrm{V}$ was significant for number of seeds/silicle and $\mathrm{T} \times \mathrm{V}$ was significant for seed yield. The interaction, $\mathrm{TU} \times \mathrm{T} \times \mathrm{V}$ was significant for seed yield. 

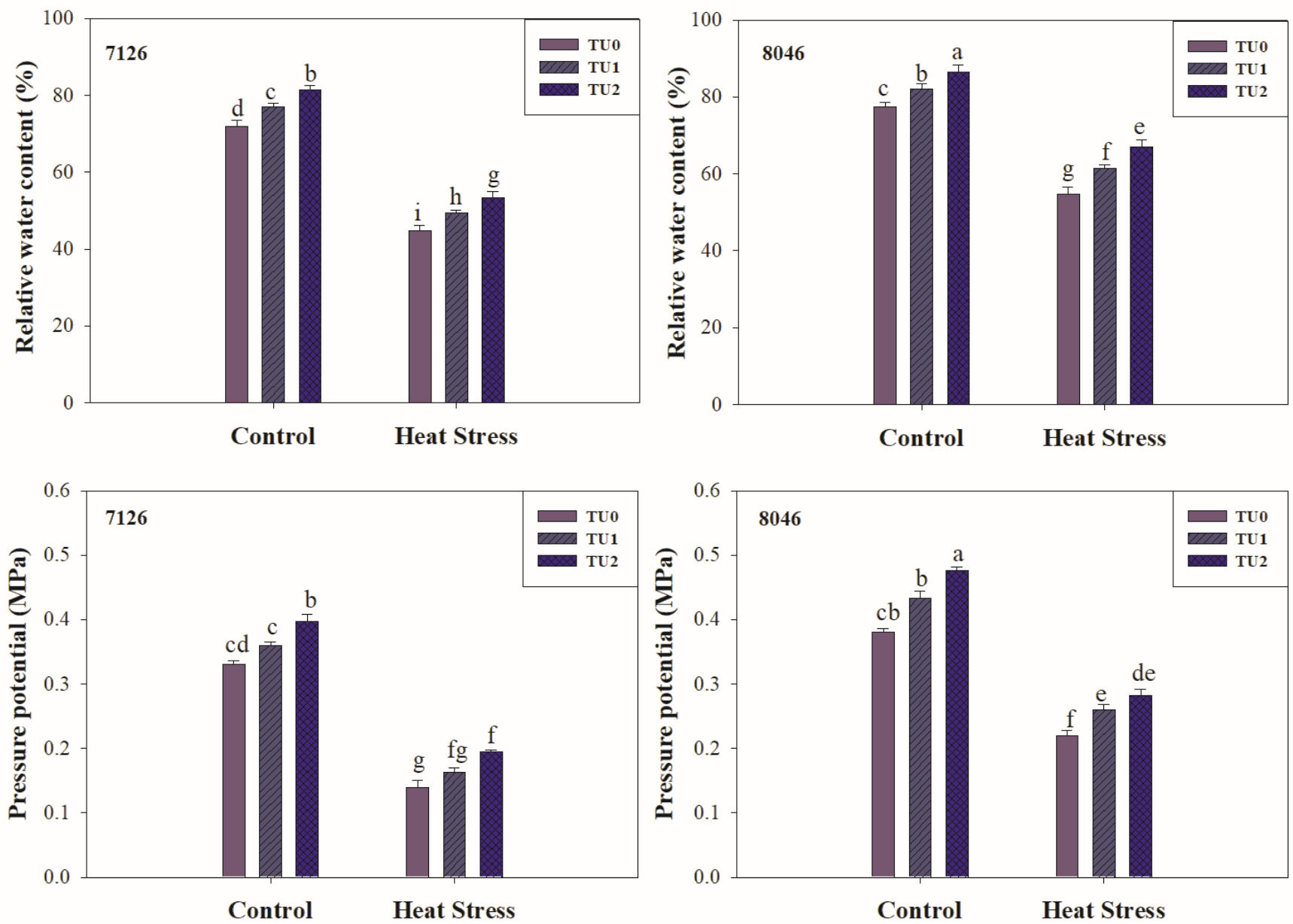

Figure 2. Impact of thiourea priming $\left(\mathrm{TU}_{0}=\right.$ control-no application, $\mathrm{TU}_{1}=$ Water priming, $\mathrm{TU}_{2}=\mathrm{Thiourea}$ priming $(500 \mathrm{ppm})$ and heat stress $\left(32{ }^{\circ} \mathrm{C}\right)$ on pressure potential $(\mathrm{MPa})$ and relative water content $(\mathrm{MPa})$ on camelina genotypes 7126 and 8046 . Error bars above means indicate the \pm S.E. Means sharing the same letter in both varieties do not differ significantly at $p \leq 0.05$.

Table 3. Impact of thiourea priming and heat stress on growth and yield parameters of two camelina varieties.

\begin{tabular}{|c|c|c|c|c|c|c|}
\hline Varieties (V) & Heat Stress $(\mathrm{T})$ & $\begin{array}{l}\text { Thiourea (TU) } \\
\text { Applications }\end{array}$ & $\begin{array}{l}\text { No. of Silicle } \\
\text { Plant }^{-1}\end{array}$ & $\begin{array}{l}\text { No. of Seeds } \\
\text { Silicle }^{-1}\end{array}$ & 1000-Seed Weight (g) & Seed Yield Pot ${ }^{-1}$ (g) \\
\hline \multirow{6}{*}{7126} & \multirow{3}{*}{ Control } & $\mathrm{TU}_{0}$ & $33.3 \pm 1.52^{\mathrm{e}}$ & $9.73 \pm 0.64^{\mathrm{e}}$ & $0.76 \pm 0.04$ ef & $2.45 \pm 0.06^{\mathrm{d}}$ \\
\hline & & $\mathrm{TU}_{1}$ & $40.6 \pm 0.57^{c}$ & $11.7 \pm 0.68^{c}$ & $0.87 \pm 0.05^{\mathrm{cd}}$ & $2.92 \pm 0.17^{b, c}$ \\
\hline & & $\mathrm{TU}_{2}$ & $45.6 \pm 1.15^{\mathrm{b}}$ & $13.6 \pm 0.57^{b}$ & $1.00 \pm 0.03^{b}$ & $3.81 \pm 0.24^{\mathrm{a}}$ \\
\hline & \multirow{3}{*}{ Heat stress } & $\mathrm{TU}_{0}$ & $23.0 \pm 1.00 \mathrm{~g}$ & $7.42 \pm 0.46^{\mathrm{h}}$ & $0.48 \pm 0.01^{\mathrm{h}}$ & $0.57 \pm 0.02^{h}$ \\
\hline & & $\mathrm{TU}_{1}$ & $27.0 \pm 1.00^{f}$ & $8.30 \pm 0.26^{\mathrm{f}, \mathrm{g}}$ & $0.53 \pm 0.01^{g}$ & $0.62 \pm 0.01^{h}$ \\
\hline & & $\mathrm{TU}_{2}$ & $32.6 \pm 0.58^{\mathrm{e}}$ & $9.66 \pm 0.58^{\mathrm{e}}$ & $0.73 \pm 0.01^{\mathrm{f}}$ & $1.31 \pm 0.24^{\mathrm{f}}$ \\
\hline \multirow{6}{*}{8046} & \multirow{3}{*}{ Control } & $\mathrm{TU}_{0}$ & $38.0 \pm 1.03^{d}$ & $10.5 \pm 0.25^{\mathrm{d}}$ & $0.81 \pm 0.01^{\mathrm{d}, \mathrm{e}}$ & $2.66 \pm 0.04^{\mathrm{c}, \mathrm{d}}$ \\
\hline & & $\mathrm{TU}_{1}$ & $44.0 \pm 1.00^{b}$ & $13.3 \pm 0.57^{b}$ & $0.89 \pm 0.02^{c}$ & $2.96 \pm 0.15^{b}$ \\
\hline & & $\mathrm{TU}_{2}$ & $50.6 \pm 1.52^{a}$ & $15.3 \pm 0.35^{\mathrm{a}}$ & $1.08 \pm 0.05^{\mathrm{a}}$ & $3.89 \pm 0.28^{a}$ \\
\hline & \multirow{3}{*}{ Heat stress } & $\mathrm{TU}_{0}$ & $28.1 \pm 1.25^{f}$ & $7.97 \pm 0.16^{\mathrm{g}, \mathrm{h}}$ & $0.53 \pm 0.01^{\mathrm{h}}$ & $0.72 \pm 0.03 \mathrm{~g}, \mathrm{~h}$ \\
\hline & & $\mathrm{TU}_{1}$ & $33.0 \pm 2.64^{\mathrm{e}}$ & $9.00 \pm 0.05^{\mathrm{e}, \mathrm{f}}$ & $0.60 \pm 0.02^{g}$ & $0.96 \pm 0.09 \mathrm{~g}$ \\
\hline & & $\mathrm{TU}_{2}$ & $36.3 \pm 0.57^{d}$ & $12.3 \pm 0.57^{c}$ & $0.84 \pm 0.02^{\mathrm{cd}}$ & $1.61 \pm 0.18^{\mathrm{e}}$ \\
\hline
\end{tabular}

Values (mean \pm standard error, $n=3$ ), LSD = least significant difference; values sharing same case letter or without lettering for a parameter do not differ significantly $(p \leq 0.05)$ by the LSD test.

\section{Discussion}

Crop productivity is mainly dependent upon environmental growth factors, which suggested that the ever rising $\mathrm{CO}_{2}$ concentration in the atmosphere is the major reason for climate change that causes temperature fluctuations at an alarming rate, leading to 
the imposition of heat stress. The suboptimal temperature at any crop growth stage imparts deleterious impacts on crops productivity including camelina. In this study, heat stress showed negative effects on crop growth and yield attributes as it reduced the photosynthetic efficiency and stomatal conductance due to reduction in leaf water status in camelina, while TU supplementation remained effective in ameliorating the negative impacts of heat stress in camelina varieties (Tables 1-3; Figures 1 and 2).

The hypothesis of the study has been accepted as results indicated that the TU supplementation has played important role to ameliorate the negative impacts of heat stress by seed priming $\left(\mathrm{TU}_{0}=\right.$ No thiourea priming, $\mathrm{TU}_{1}=$ Water priming, $\mathrm{TU}_{2}=$ Thiourea priming $)$, which lead to improving the seed yield. High temperature hampered plant growth by causing a reduction in morpho-physiological attributes in camelina varieties. Among the seed priming techniques tested in this study, TU-osmopriming (TU priming at $500 \mathrm{ppm}$ ) remained an effective technique to improve the performance of camelina varieties under heat stress, as TU application boosted stomatal conductance that might be attributed to an increase in photosynthetic rate, which conferred the resistance against heat stress through physiological regulations (Tables 1-3 and Figures 1 and 2). Indeed, TU priming ameliorated the negative impacts of heat stress, regulated plant growth, improved the water status to facilitate the stomatal conductance, and also acted as a compatible osmolyte, which assisted plants to cope with heat stress. The present study confirmed a significant reduction in plant height, roots, and shoot lengths along with their fresh and dry weights under heat stress, while more reduction was observed in the control treatment (no TU-priming).

Temperature above threshold level increased the physiological activities, which consequently fastened the crop growth rate that further reduced the growth period of crops $[39,40]$. This reduction in the growth period led to the premature completion of phenological plant parts that could damage the final yield. Results showed that heat stress reduced the physiological attributes including photosynthetic rate, stomatal conductance, transpiration rate, and intercellular $\mathrm{CO}_{2}$ concentration under control-no priming as compared to TU osmopriming. Results have shown that the transpiration rate was increased due to high temperature stress, which leads to disturb plant water status; however, it modulated higher water loss, which was primarily caused by heat stress. Heat stress reduced the photosynthetic rate, which is more prone to heat damages that lead to reduce crop growth and grain yield [41,42]. Heat stress negatively affected the reproductive growth that disturbed the seed formation process which may reduce the number of seed pod $^{-1}$ and seed weight $[43,44]$, because high-temperature stress affects the source-sink relationship and explain the differences in seed yield [45]. Among the gas exchange attributes, results exhibited that heat stress restricted the rate of $\mathrm{CO}_{2}$ assimilation as indicated by lower photosynthetic efficiency, transpiration rate, and stomatal conductance, while intercellular $\mathrm{CO}_{2}$ concentration was increased, which showed the negative effect of heat stress on the stomatal component of photosynthesis; nevertheless, it also hampered the assimilation of absorbed $\mathrm{CO}_{2}$. The reduction in the photosynthetic efficiency resulted in reducing the assimilation formation and translocation towards the sink, which led to reduce the seed yield and related attributes [18]. Heat stress at the reproductive stage could damage the seed formation processes including flowering and seed set that hampered the rate of grain filling and grain yield [46]. High temperature directly affected the crop water relations as water potential, osmotic potential, pressure potential, and relative water content were decreased by $31.9,6.72,46.9$, and $30.6 \%$ as compared to control-no stress with more reduction in no-TU treatment (Figures 1 and 2). Reduction in plant water status effects the turgidity of the cell that directly effects the elongation of the cell, which leads to reduce the crop growth.

Pre-sowing seed treatment was the foundation for the early activation of seed metabolism that in combination with other elements might be helpful to the proper vegetative growth and higher seed yield. The survival of plants under stress conditions could be possible by the supplementation of stress alleviating chemical compounds $[47,48]$, like TU, that can potentially upregulate the plant defense to improve plant tolerance under stressed 
conditions [49]. The applications of TU manifolds growth regulatory roles in plant species including camelina varieties. Our results depicted that exogenous application of TU as a seed priming treatment improved the seed yield of both camelina varieties under heat stress conditions compared to control (Table 3 ). The TU priming significantly improved the yield attributes including plant height, root and shoot lengths along with their fresh and dry weights indicating higher biomass accumulation triggered by TU which is in line with the findings of Asthir et al. [40]. The sulfhydryl TU not only increased the root length but also increased branching in roots under heat stress that tends to increase the root fresh and dry weight. The ascribed TU-induced increase in growth could be due to the mediation of a number of important metabolic functions.

Thus, seed priming with TU offered a promising and economical solution for improving crop resistance against heat stress [17]. Plants treated with TU exhibited maximum biomass accumulation as compared to control-no TU applied, indicating the positive role of TU in boosting plant growth by alleviating the adverse effects of heat stress (Table 1). In addition, osmoprimed crops could timely complete all the phenological events, and this phenological plasticity can be helpful when integrated with high-temperature stress to avoid their negative effects on crop growth and development during early and later reproductive stages without yield penalty. TU supplementation reduced heat stress-induced oxidative stress by upregulating the important phenomenon of photosynthesis, and assimilate translocation which was also reported by Patade et al. [27] to enhance the defense system in camelina plants to impart heat stress. The TU-supplementation improved the seed weight and consequently gave higher seed yield per pot in both varieties under heat stress conditions as compared to control-no TU priming at the same conditions. This can be attributed to the improvement in plant metabolism, which enabled the plant defense against heat stress [50]. In the current study, TU priming (500 ppm) helped to increase photosynthetic rate and stomatal conductance [48]; however, the net $\mathrm{CO}_{2}$ assimilation rate was more with TU priming than control-no TU applied.

The possible reason for this variation in photosynthetic rate may be that TU application increased the leaf growth which in turn up-folded the photosynthetic rate by increasing the harvesting of photosynthetically active light (Table 2). Thiourea supplementation at any growth stage and through any methods of applications may improve the photosynthetic apparatus in plants that helped the plants to maintain photosynthetic rate [51,52]. In the present study, exogenous use of TU as pre-sowing seed treatment was found effective in decreasing the damages caused by heat stress. Additionally, the TU-applied reduction in intercellular $\mathrm{CO}_{2}$ concentration rate might be due to the effective role of TU metabolites in the regulation of activities of antioxidative enzymes (Table 2). Available reports support the present findings where seed priming with different compounds was found effective in improving the plant physiological attributes [53-55]. Our results are in line with Orman and Kaplan [56], who reported that TU application increased the biomass of tomato plants by $6-8 \%$ grown in sandy loam soil. TU at either stage performed well to alleviate heat induced damages, while, TU supplementation at vegetative stage improved plant height, root length, and dry weight compared to TU applied at the vegetative growth stage [48,57]. In addition, TU supplementation upregulated the plant water relations which played significant role to improve the stomatal conductance as compared to no-TU application in line with the findings of Ahmad et al. [18].

The results have shown variability among two varieties of camelina under heatstressed conditions, as 8046 has shown more resistance to the deleterious effects of heat stress as compared to variety 7126 . Variety 8046 has shown better performance in relation to plant growth attributes as compared to 7126 , as plant height and root length were maximum in 8046 and minimum in 7126 (Table 1). The impact of heat stress-induced damages is cultivar-specific depending on the extent of tolerance based on various tolerance mechanisms including the cellular oxidative defenses in terms of the enzymatic and nonenzymatic antioxidant compounds [58-60]. The endogenous content of photosynthetic pigments with $\mathrm{CO}_{2}$ assimilation rate was also affected in heat susceptible variety (7126) 
as compared to heat resistant variety (8046), which is in line with the findings of [61]. Almeselmani et al. [62] and Balla et al. [63] have also noted that the activities of plant defense system upregulated the plant physiological attributes including photosynthetic rate and stomatal conductance while decreasing intercellular $\mathrm{CO}_{2}$ concentration intolerant variety (8046), but downregulated insensitive variety (7126) under high-temperature stress. However, variety 8046 was not so affected and sustained its biomass, photosynthetic rate, plant water status, and seed yield as compared to 7126 (Figures 1 and 2).

\section{Conclusions}

Heat stress imparted deleterious effects on photosynthesis and plant water status that led to reduce the plant growth and yield in camelina varieties. Nevertheless, osmoriming with thiourea (500 ppm) improved the growth and yield of both varieties of camelina under normal and heat-stressed conditions. Thiourea priming upregulated the plant water relations to regulate stomatal conductance and photosynthetic efficiency, which added to improve crop yield. It was also inferred that camelina variety 8046 performed better against heat stress as compared to 7126 grown under high-temperature stress. Overall, this study provides a good understanding for scientists to find out the actual physiological mechanisms behind the thiourea induced heat stress tolerance mechanism in camelina that will be a roadmap for the further investigation at cellular level.

Author Contributions: Conceptualization, E.A.W., M.A. and M.T.M.; methodology, M.T.M., M.A.; software, A.E.S.; validation, E.A.W., Z.A., M.H.-U.-R., W.S. and A.E.S.; formal analysis, Z.A.; investigation, M.A., M.T.M., Z.A.; resources, EA.W and A.E.S.; data curation, W.S., A.E.S., M.A.; writing-original draft preparation, E.A.W., M.A., M.T.M. and A.E.S.; writing-review and editing, M.A., M.H.-U.-R., W.S. and A.E.S. and supervision, E.A.W.; funding acquisition, W.S. All authors have read and agreed to the published version of the manuscript.

Funding: This Research was funded by the Researchers Supporting Project number (RSP-2021/390), King Saud University, Riyadh, Saudi Arabia.

Institutional Review Board Statement: Not applicable.

Informed Consent Statement: Not applicable.

Data Availability Statement: Data is contained within the article.

Acknowledgments: This research was funded by the Researchers Supporting Project number (RSP2021/390), King Saud University, Riyadh, Saudi Arabia.

Conflicts of Interest: The authors declare no conflict of interest.

\section{References}

1. Faisal, M.; Iqbal, M.A.; Aydemir, S.K.; Hamid, A.; Rahim, N.; El Sabagh, A.; Khaliq, A.; Siddiqui, M.H. Exogenously foliage applied micronutrients efficacious impact on achene yield of sunflower under temperate conditions. Pak. J. Bot. 2020, 52, 1215-1221. [CrossRef]

2. Mahajan, S.; Tuteja, N. Cold, salinity and drought stresses: An overview. Arch. Biochem. Biophys. 2005, 444, 139-158. [CrossRef]

3. IPCC. IPCC Expert Meeting Report: Towards New Scenarios for Analysis of Emissions, Climate Change, Impacts, and Response Strategies; IPCC Secretariat: Geneva, Switzerland, 2007.

4. NASA. What Is Climate Change? Available online: https://climatekids.nasa.gov/climate-change-meaning/ (accessed on 14 May 2019).

5. Olesen, J.E.; Bindi, M. Consequences of climate change for European agricultural productivity, land use and policy. Eur. J. Agron. 2002, 16, 239-262. [CrossRef]

6. Ahmad, Z.; Waraich, E.A.; Ahmad, R.; Shahbaz, M. Modulation in water relations, chlorophyll contents and antioxidants activity of maize by foliar phosphorus application under drought stress. Pak. J. Bot. 2017, 49, 11-19.

7. Stern, N. Stern Review: The Economics of Climate Change; Cambridge University Press: Cambridge, UK, 2006.

8. Wise, R.R.; Olson, A.J.; Schrader, S.M.; Sharkey, T.D. Electron transport is the functional limitation of photosynthesis in field-grown Pima cotton plants at high temperature. Plant Cell Environ. 2004, 27, 717-724. [CrossRef]

9. Ribeiro, R.V.; Machado, E.C.; Oliveira, R.F. Temperature response of photosynthesis and its interaction with light intensity insweet orange leaf discs under non-photorespiratory condition. Ciênc. Agrotecnol. 2006, 30, 670-678. [CrossRef] 
10. Rout, G.R.; Das, A.B. Molecular Stress Physiology of Plants; Springer: New Delhi, India, 2013; ISBN 978-81-322-0806-8.

11. Ahanger, M.A.; Akram, N.A.; Ashraf, M.; Alyemeni, M.N.; Wijaya, L.; Ahmad, P. Plant responses to environmental stresses-Fromgene to biotechnology. AoB Plants. 2017, 1, 9.

12. Kumar, S.; Kaur, R.; Kaur, N.; Bhandhari, K.; Kaushal, N.; Gupta, K.; Bains, T.S.; Nayyar, H. Heat-stress induced inhibition ingrowth and chlorosis in mungbean (Phaseolus aureus Roxb.) is partly mitigated by ascorbic acid application and is related toreduction in oxidative stress. Acta Physiol. Plant. 2011, 33, 2091-2101. [CrossRef]

13. Rai, A.C.; Singh, M.; Shah, K. Effect of water withdrawal on formation of free radical, proline accumulation and activities of antioxidant enzymes in ZAT12-transformed transgenic tomato plants. Plant Physiol. Biochem. 2012, 61, 108-114. [CrossRef]

14. Hasanuzzaman, M.; Hossain, M.A.; Silva, J.A.T.D.; Fujita, M. Plant response and tolerance to abiotic oxidative stress: Antiox-idant defense is a key factor. In Crop Stress and Its Management: Perspectives and Strategies; Venkateswarlu, B., Shanker, A.K., Shanker, C., Maheswari, M., Eds.; Springer: Dordrecht, The Netherlands, 2012; pp. 261-315.

15. Morrison, M.J.; Stewart, D.W. Heat stress during flowering in summer Brassica. Crop Sci. 2002, 42, 797-803. [CrossRef]

16. Carmo-Silva, A.E.; Gore, M.A.; Andrade-Sanchez, P.; French, A.N.; Hunsaker, D.J.; Salvucci, M.E. Decreased $\mathrm{CO}_{2}$ availability and inactivation of Rubisco limit photosynthesis in cotton plants under heat and drought stress in the field. Environ. Exp. Bot. 2012, 83, 1-11. [CrossRef]

17. Ahmad, M.; Waraich, E.A.; Tanveer, A.; Anwar-Ul-Haq, M. Foliar Applied Thiourea Improved Physiological Traits and Yield of Camelina and Canola Under Normal and Heat Stress Conditions. J. soil Sci. Plant Nutr. 2021, 21, 1666-1678. [CrossRef]

18. Chen, S.; Stefanova, K.; Siddique, K.H.M.; Cowling, W.A. Transient daily heat stress during the early reproductive phase disrupts pod and seed development in Brassica napus L. Food Energy Secur. 2021, 10, 262. [CrossRef]

19. Ihsan, M.Z.; Daur, I.; Alghabari, F.; Alzamanan, S.; Rizwan, S.; Ahmad, M.; Waqas, M.; Shafqat, W. Heat stress and plant development: Role of sulphur metabolites and management strategies. Acta Agric. Scand. Sect. B—Plant Soil Sci. 2019, 69, 332-342. [CrossRef]

20. Dawood, M.G. Stimulating Plant Tolerance against Abiotic Stress Through Seed Priming. In Advances in Seed Priming; Springer International Publishing: Cham, Switzerland, 2018; pp. 147-183.

21. Ahmad, Z.; Waraich, E.A.; Barutçular, C.; Alharby, H.; Bamagoos, A.; Kizilgeci, F.; Öztürk, F.; Hossain, A.; Bayoumi, Y.; El Sabagh, A. Enhancing drought tolerance in Camelina sativa L. and Canola napus L. through application of selenium. Pak. J. Bot. 2020, 52, 1927-1939. [CrossRef]

22. Dutta, P. Seed Priming: New Vistas and Contemporary Perspectives. In Advances in Seed Priming; Springer: Singapore, 2018; pp. 3-22.

23. Nathawat, N.S.; Nair, J.S.; Kumawat, S.M.; Yadava, N.S.; Singh, G.; Ramaswamy, N.K.; Sahu, M.P.; D'Souza, S.F. Effect of seed soaking with thiols on the antioxidant enzymes and photosystem activities in wheat subjected to water stress. Biol. Plant. 2007, 51, 93-97. [CrossRef]

24. Hasanuzzaman, M.; Bhuyan, M.H.M.B.; Mahmud, J.A.; Nahar, K.; Mohsin, S.M.; Parvin, K.; Fujita, M. Interaction of sulfur with phytohormones and signaling molecules in conferring abiotic stress tolerance to plants. Plant Signal. Behav. 2018, 13, e1477905. [CrossRef] [PubMed]

25. Skudra, I.; Ruza, A. Effect of Nitrogen and Sulphur Fertilization on Chlorophyll Content in Winter Wheat. Rural. Sustain. Res. 2017, 37, 29-37. [CrossRef]

26. Pandey, M.; Srivastava, A.K.; D'Souza, S.F.; Penna, S. Thiourea, a ROS scavenger, regulates source-to-sink relationship to enhance crop yield and oil content in Brassica juncea (L.). PLoS ONE 2013, 8, e73921.

27. Patade, V.Y.; Nikalje, G.C.; Srivastava, S. Role of Thiourea in Mitigating Different Environmental Stresses in Plants. In Protective Chemical Agents in the Amelioration of Plant Abiotic Stress: Biochemical and Molecular Perspectives; Roychoudhury, A., Tripathi, D.K., Eds.; John Wiley \& Sons: Hoboken, NJ, USA, 2020; pp. 467-482. [CrossRef]

28. Akladious, S.A. Influence of thiourea application on some physiological and molecular criteria of sunflower (Helianthus annuus L.) plants under conditions of heat stress. Protoplasma 2013, 251, 625-638. [CrossRef]

29. Ahmad, M.; Waraich, E.A.; Zulfiqar, U.; Ullah, A.; Farooq, M. Thiourea application improves heat tolerance in camelina (Camelina sativa L. Crantz) by modulating gas exchange, antioxidant defense and osmoprotection. Ind. Crop. Prod. 2021, 170, 113826. [CrossRef]

30. Hao, Z.; Singh, V.P. Drought characterization from a multivariate perspective: A review. J. Hydrol. 2015, 527, 668-678. [CrossRef]

31. Righini, D.; Zanetti, F.; Martínez-Force, E.; Mandrioli, M.; Toschi, T.G.; Monti, A. Shifting sowing of camelina from spring to autumn enhances the oil quality for bio-based applications in response to temperature and seed carbon stock. Ind. Crop. Prod. 2019, 137, 66-73. [CrossRef]

32. Righini, D.; Zanetti, F.; Monti, A. The bio-based economy can serve as the springboard for camelina and crambe to quit the limbo. OCL 2016, 23, D504. [CrossRef]

33. Gesch, R.; Dose, H.; Forcella, F. Camelina growth and yield response to sowing depth and rate in the northern Corn Belt USA. Ind. Crop. Prod. 2017, 95, 416-421. [CrossRef]

34. Murphy, E.J. Camelina (Camelina sativa). In Industrial Oil Crops; Elsevier BV: Amsterdam, The Netherlands, 2016 ; pp. $207-230$.

35. Zubr, J. Qualitative variation of Camelina sativa seed from different locations. Ind. Crop. Prod. 2003, 17, 161-169. [CrossRef] 
36. Dixon, G.R. Vegetable Brassicas and Related Crucifers (No. 14); CABI: Wallingford, UK, 2007.

37. Zanetti, F.; Eynck, C.; Christou, M.; Krzyżaniak, M.; Righini, D.; Alexopoulou, E.; Stolarski, M.J.; van Loo, E.N.; Puttick, D.; Monti, A. Agronomic performance and seed quality attributes of Camelina (Camelina sativa L. crantz) in multi-environment trials across Europe and Canada. Ind. Crops Prod. 2017, 107, 602-608. [CrossRef]

38. Steel, R.G.D.; Torrie, J.H.; Deekey., D.A. Principles and Procedures of Statistics. In A Biometrical Approach; McGraw Hill Book. Int. Co.: New York, NY, USA, 1997; pp. 400-428.

39. Fahad, S.; Hussain, S.; Saud, S.; Hassan, S.; Ihsan, Z.; Shah, A.N.; Wu, C.; Yousaf, M.; Nasim, W.; Alharby, H.; et al. Exogenously Applied Plant Growth Regulators Enhance the Morpho-Physiological Growth and Yield of Rice under High Temperature. Front. Plant Sci. 2016, 7, 1250. [CrossRef] [PubMed]

40. Asthir, B.; Thapar, R.; Farooq, M.; Bains, N.S. Exogenous application of thiourea improves the performance of late sown wheat by inducing terminal heat resistance. Int. J. Agric. Biol. 2013, 15, 1337-1342.

41. Allakhverdiev, S.I.; Kreslavski, V.D.; Klimov, V.V.; Los, D.; Carpentier, R.; Mohanty, P. Heat stress: An overview of molecular responses in photosynthesis. Photosynth. Res. 2008, 98, 541-550. [CrossRef] [PubMed]

42. Fahad, S.; Hussain, S.; Saud, S.; Hassan, S.; Chauhan, B.; Khan, F.; Ihsan, M.Z.; Ullah, A.; Wu, C.; Bajwa, A.; et al. Responses of Rapid Viscoanalyzer Profile and Other Rice Grain Qualities to Exogenously Applied Plant Growth Regulators under High Day and High Night Temperatures. PLoS ONE 2016, 11, e0159590. [CrossRef]

43. Jiang, Y. Effect of heat stress on pollen development and seed set of field pea (Pisum sativum L.). Ph.D. Thesis, University of Saskatchewan, Saskatoon, SK, Canada, 2016.

44. Farooq, M.; Bramley, H.; Palta, J.; Siddique, K. Heat Stress in Wheat during Reproductive and Grain-Filling Phases. Crit. Rev. Plant Sci. 2011, 30, 491-507. [CrossRef]

45. Weymann, W.; Böttcher, U.; Sieling, K.; Kage, H. Effects of weather conditions during different growth phases on yield formation of winter oilseed rape. Field Crop. Res. 2015, 173, 41-48. [CrossRef]

46. Afzal, I.; Basra, S.; Shahid, M.; Farooq, M.; Saleem, M. Priming enhances germination of spring maize (Zea mays L.) under cool conditions. Seed Sci. Technol. 2008, 36, 497-503. [CrossRef]

47. Farooq, M.; Wahid, A.; Kobayashi, N.; Fujita, D.; Basra, S.M.A. Plant drought stress: Effects, mechanisms and management. Agron. Sustain. Dev. 2009, 29, 185-212. [CrossRef]

48. Ali, M.M.; Shafique, M.W.; Gull, S.; Naveed, W.A.; Javed, T.; Yousef, A.F.; Mauro, R.P. Alleviation of Heat Stress in Tomato by Exogenous Application of Sulfur. Horticulturae 2021, 7, 21. [CrossRef]

49. Singh, S.; Rathore, P. Influence of phosphorus and thiourea on yield and economics of greengram [Vigna radiata var. aureus (L.) Wilczek]. Res. Crop. 2003, 4, 210-212.

50. Ahmad, M.; Waraich, E.A.; Hussain, S.; Ayyub, C.M.; Ahmad, Z.; Zulfiqar, U. Improving Heat Stress Tolerance in Camelina sativa and Brassica napus Through Thiourea Seed Priming. J. Plant Growth Regul. 2021, 1-17. [CrossRef]

51. Rezaei, M.; Bagherian, F. Influence of planting date and sulfur coating in seed coating solution on cotton (Gossypium hirsutum L.) seeds: Physiological traits. Iran. J. Plant Physiol. 2013, 4, 917-923.

52. Brooks, A. Effects of Phosphorus Nutrition on Ribulose-1,5-Bisphosphate Carboxylase Activation, Photosynthetic Quantum Yield and Amounts of Some Calvin-Cycle Metabolites in Spinach Leaves. Funct. Plant Biol. 1986, 13, 221-237. [CrossRef]

53. Ibrahim, E.A. Seed priming to alleviate salinity stress in germinating seeds. J. Plant Physiol. 2016, 192, 38-46. [CrossRef] [PubMed]

54. Kaya, C.; Ashraf, M.; Sonmez, O.; Tuna, A.L.; Polat, T.; Aydemir, S. Exogenous application of thiamin promotes growth and antioxidative defense system at initial phases of development in salt-stressed plants of two maize cultivars differing in salinity tolerance. Acta Physiol. Plant. 2014, 37, 1741 . [CrossRef]

55. Mobin, M.; Khan, M.N.; Abbas, Z.K.; Ansari, H.R.; Al-Mutairi, K. Significance of sulfur in heat stressed cluster bean (Cymopsis tetragonoloba L. Taub) genotypes: Responses of growth, sugar and antioxidative metabolism. Arch. Agron. Soil Sci. 2016, 63, 288-295. [CrossRef]

56. Orman, S.; Kaplan, M. Effects of elemental sulphur and farmyard manure on $\mathrm{pH}$ and salinity of calcareous sandy loam soil and some nutrient elements in tomato plant. J. Agric. Sci. Technol. 2011, 5, 20-26.

57. Sohag, A.A.M.; Arif, T.-U.; Brestic, M.; Afrin, S.; Sakil, A.; Hossain, T.; Hossain, M.A.; Hossain, A. Exogenous salicylic acid and hydrogen peroxide attenuate drought stress in rice. Plant Soil Environ. 2020, 66, 7-13. [CrossRef]

58. Ali, Q.; Daud, M.; Haider, M.Z.; Ali, S.; Rizwan, M.; Aslam, N.; Noman, A.; Iqbal, N.; Shahzad, F.; Deeba, F.; et al. Seed priming by sodium nitroprusside improves salt tolerance in wheat (Triticum aestivum L.) by enhancing physiological and biochemical parameters. Plant. Physiol. Biochem. 2017, 119, 50-58. [CrossRef]

59. Javeed, H.; Ali, M.; Skalicky, M.; Nawaz, F.; Qamar, R.; Rehman, A.; Faheem, M.; Mubeen, M.; Iqbal, M.; Rahman, M.; et al. Lipoic Acid Combined with Melatonin Mitigates Oxidative Stress and Promotes Root Formation and Growth in Salt-Stressed Canola Seedlings (Brassica napus L.). Molecules 2021, 26, 3147. [CrossRef] [PubMed]

60. Ahmad, Z.; Anjum, S.; Skalicky, M.; Waraich, E.; Tariq, R.M.S.; Ayub, M.; Hossain, A.; Hassan, M.; Brestic, M.; Islam, M.S.; et al. Selenium Alleviates the Adverse Effect of Drought in Oilseed Crops Camelina (Camelina sativa L.) and Canola (Brassica napus L.). Molecules 2021, 26, 1699. [CrossRef] 
61. Marchand, F.L.; Mertens, S.; Kockelbergh, F.; Beyens, L.; Nijs, I. Performance of High Arctic tundra plants improved during but deteriorated after exposure to a simulated extreme temperature event. Glob. Chang. Biol. 2005, 11, 2078-2089. [CrossRef]

62. Almeselmani, M.; Deshmukh, P.S.; Sairam, R.K. High temperature stress tolerance in wheat genotypes: Role of antioxidant defence enzymes. Acta Agron. Hung. 2009, 57, 1-14. [CrossRef]

63. Balla, K.; Bencze, S.; Janda, T.; Veisz, O. Analysis of heat stress tolerance in winter wheat. Acta Agron. Hung. 2009, 57, 437-444. [CrossRef] 